\title{
Pulmonary Manifestations of Primary Sjögren's Syndrome: Underlying Immunological Mechanisms, Clinical Presentation, and Management
}

\author{
Sarthak Gupta ${ }^{\dagger}$, Marcela A. Ferrada ${ }^{\dagger}$ and Sarfaraz A. Hasni * \\ National Institute of Arthritis and Musculoskeletal and Skin Diseases, National Institutes of Health, Bethesda, MD,
} United States

Pulmonary involvement in primary Sjögren's syndrome (pSS) is an understudied entity with important clinical implications. Its prevalence has been reported in up to $20 \%$ of pSS patients. Pulmonary manifestations of pSS are diverse with involvement of airway and/or lung parenchyma. Histopathology of lung lesions suggests a predominance of

OPEN ACCESS

Edited by:

Clio Mavragani,

National and Kapodistrian University

of Athens, Greece

Reviewed by:

Jessica Borger,

Monash University, Australia

Sophia Davidson,

Walter and Eliza Hall Institute of

Medical Research, Australia

*Correspondence:

Sarfaraz A. Hasni

hasnisa@mail.nih.gov

${ }^{\dagger}$ These authors have contributed equally to this work

Specialty section:

This article was submitted to Inflammation,

a section of the journal

Frontiers in Immunology

Received: 26 October 2018 Accepted: 24 May 2019

Published: 12 June 2019

Citation:

Gupta S, Ferrada MA and Hasni SA (2019) Pulmonary Manifestations of

Primary Sjögren's Syndrome: Underlying Immunological Mechanisms, Clinical Presentation, and Management

Front. Immunol. 10:1327. doi: 10.3389/fimmu.2019.01327 submucosal mononuclear cell infiltration consisting predominantly of CD4+ T cells. Current understanding of the pathophysiology of lung disease in pSS suggests a similar process driving the pulmonary process as those in the salivary glands, with epithelial cells playing a critical role in the initiation, maintenance, and symptomatology of the disease. Clinical manifestations of lung involvement in pSS are as varied as the underlying pathology and can be vague and non-specific, thus delaying diagnosis. Management options depend on the underlying pathology but are generally limited due to lack of systematic randomized controlled trials. This review helps summarize our current understanding of lung involvement in pSS.

Keywords: primary Sjögren's syndrome, interstitial lung disease, ILD, pulmonary manifestations, pSS, lung involvement

\section{INTRODUCTION}

Primary Sjögren's syndrome (pSS) is a progressive systemic autoimmune disease primarily affecting females that is manifested by inflammatory lymphocytic infiltrate of exocrine glands like lachrymal and salivary that lead to the destruction of the tissue. It is characterized by dry mouth and eyes, parotid swelling, profound fatigue, widespread musculoskeletal pain, and polyarthritis (1). Its prevalence is estimated at $0.5-4 \%$, making it one of the most prevalent multisystem autoimmune disease after rheumatoid arthritis (2-4). Apart from dry eyes and dry mouth, pSS has multiple systemic manifestations including polyarthritis, autonomic dysfunction, pancreatitis, vasculitis, renal involvement, lymphoma, fatigue, increased immunoglobulin, hypocomplementemia, and lung involvement (5).

Similar to other systemic autoimmune diseases, Sjögren's syndrome develops in genetically predisposed individuals, who are exposed to various environmental factors resulting in a dysfunctional immune system response to self-antigens. The impaired immune system cascades by activation of innate immune response along with activation of glandular epithelial cells that in turn leads to activation of B and T lymphocytes resulting in eventual damage of the target organs (6).

The lung manifestations of pSS are varied and include airway abnormalities and interstitial lung disease (ILD) (7). Even though it may be present in nearly a fifth of pSS patients, it is an 


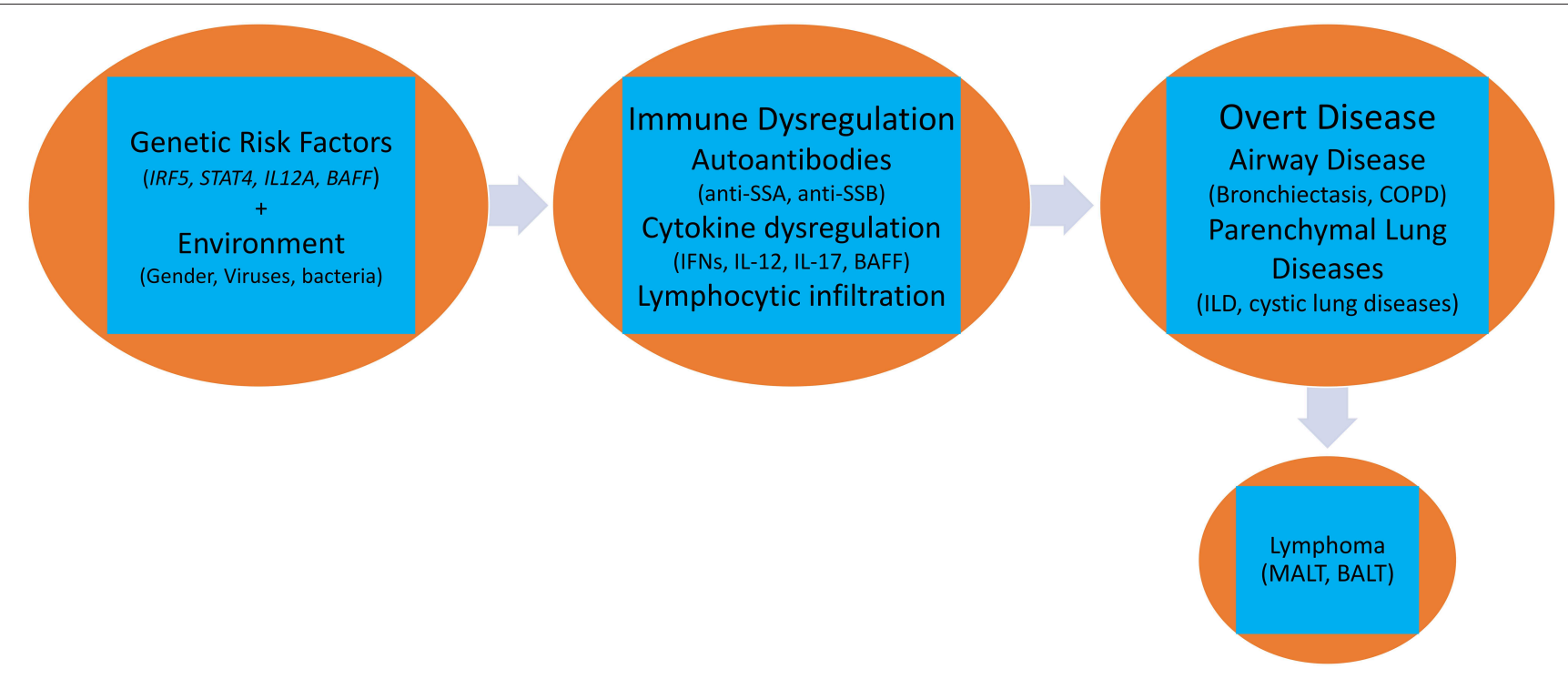

FIGURE 1 | Pathogenesis of pulmonary involvement in Sjögren's syndrome.

understudied entity with important clinical implications. Patients with pulmonary involvement have decreased quality of life and increased mortality as compared with patients with pSS with no pulmonary involvement $(8,9)$ This review summarizes our current understanding of the pulmonary manifestations of pSS and includes clinical management of this entity.

\section{PREVALENCE OF LUNG DISEASE IN SJÖGREN'S SYNDROME}

The pulmonary manifestations of pSS are diverse with airway disease and ILD being the most predominant presentations. Additionally, the manifestations differ in severity and this could in part explain the wide variability in the reported prevalence of this entity. The prevalence of clinically significant pSS lung disease have been reported from 9 to up to $20 \%(10-12)$. However, the estimates of prevalence increase significantly (43$75 \%$ ) on comprehensive evaluation with imaging modalities and pulmonary function tests, suggesting a wider subclinical presentation (13). Computed Tomography (CT) scans of pSS patients have shown lung changes in up to $34-50 \%$ of patients $(13,14)$. In one study, the annual incidence of pulmonary manifestation like ILD has been estimated at $10 \%$ at just 1 year of diagnosis and increases to nearly $20 \%$ by 5 years (15).

\section{PATHOGENESIS}

The primary histological lesion of pSS is progressive focal lymphocytic infiltrate around the salivary and lachrymal ducts that gradually extends and replaces the physiological glandular epithelium leading to dry eyes and dry mouth. Mononuclear cells, enriched in CD4+ T-cells, are found to infiltrate these lesions (16). Interestingly, similar lesions have been seen in extraglandular organs like kidneys (17-19), and liver (20) and also, in lung lesions. Additionally, increased lymphocytic infiltration of salivary glands, quantified by focus score, has been shown to correlate with increased prevalence of airway and interstitial lung disease in pSS (21). All these findings suggest that the pathways leading to glandular and extraglandular manifestations of pSS are similar and involve development of autoimmunity to epithelial cells, and that epithelium plays a key role in pSS pathogenesis.

A complex interaction of genetic, environmental, and hormonal factors has been implicated in the pathogenesis of pulmonary pSS. Activation of several biological pathways belonging to both innate and acquired immune systems such as Type I and II interferons (IFN) (22), aberrant Tregulatory activity (23), augmented function of helper T-cells (24), lymphoneogenesis with germinal center formation, and abnormal B-cell activation with clonal expansion of B-cells (25) has been reported (Figure 1).

However, it is still unclear why epithelial cells like those present in the airway or lung parenchyma are targeted in pSS. This could be an extension of the immune response that originated in the salivary glands and subsequently affects other epithelial cells in the body. Activation of $\mathrm{B}$ and $\mathrm{T}$ cell responses against shared common antigens like ion-transport channel, enzymes like carbonic anhydrase, or muscarinic receptors that are expressed in all epithelial cells have been reported in pSS $(26,27)$. Autoantibodies against M3 muscarinic receptor may also lead to compensatory increase in M3R expression resulting in cholinergic hyperresponsiveness as seen in some pSS with hyper-reactive airway disease (28).

Alternatively, studies have also implicated viruses (29) and bacteria (30) that have a specific tropism for epithelial cells as initial drivers of disease; however, a specific responsible agent 
has not been conclusively identified. For example, human Tlymphotropic virus type $1(\mathrm{HTLV}-1)$ is one of the pathogens reportedly attributed in pSS pathogenesis $(31,32)$. Anti-HTLV1 antibodies are significantly more prevalent in pSS patients with airway disease than without (21). Interestingly, HTLV-1 lung infection, even in the absence of any connective tissue disease, has been associated with radiographic and pathological findings consistent with lymphocytic bronchiolitis and ILD (3335). Additionally, $\mathrm{p} 40^{\text {tax }}$, a regulatory component of HTLV-1 that has the ability to induce multiple host genes including pro-inflammatory cytokines like IFN $\gamma$, is highly expressed in BAL from patients with HTLV-1 bronchiolitis (36). BAL from these patients also have increased numbers of activated T-cells (35). The similarities in the lung manifestations in HTLV-1 infection and that seen in patients with pulmonary pSS suggests a possible role of HTLV-1 in pathogenesis of pSS lung.

Individuals with aberrations in innate immune molecules like surfactant protein-D (SP-D) may also develop altered immune responses to viral or bacterial pathogens. SP-D is a member of the collectin family, pattern-recognition molecules which bind to carbohydrate moieties presented on a variety of pathogens and help in neutralization and clearance of microorganisms $(37,38)$. It is primarily synthesized by alveolar type II cells and its receptor is expressed on endothelial cells, B-cells, and antigen presenting cells (APCs). SP-D has been found to be decreased in serum from pSS patients with bronchiectasis, suggesting a possible role in pathogenesis (39). Interestingly, active pulmonary inflammation as seen in ILD due to pSS leads to increased circulating SP-D and may be beneficial as a serum biomarker.

Epithelial damage, either due to pathogen or due to genetic predisposition, and altered immune responses result in apoptosis and could be responsible for release of autoantigens (40), which may in turn lead to epitope spreading and damage of other epithelial cells in the body. Notably, SSA, Sjögren's syndrome related antigen A, a key autoantigen in pSS, redistributes during apoptosis of glandular cells and can be presented along with major histocompatibility complex (MHC) class II molecules on membrane of these apoptotic cells, and on the apoptotic bodies to induce an antibody response $(41,42)$. The presence of autoantibodies to SSA long before clinical manifestation of pSS suggests a prolonged subclinical phase with multiple or recurrent hits. The strong association of anti-SSA antibodies to pulmonary pSS manifestations also suggests ongoing damage to the pulmonary epithelial cells as a possible driver of pulmonary pSS pathogenesis.

It is likely that the patho-biology driving the disease in salivary glands is also responsible for the lung manifestations, where eventually, release of autoantigens results in stimulation of intrinsic cellular responses with engagement of toll-like receptors (TLRs), like TLR3 (43) in epithelial cells, and TLR7 and TLR8 in plasmacytoid dendritic cells (pDCs), that results in local up-regulation of Type I IFNs and IL-12 (44-46). Increase in Type I IFNs induces release of B-cell activating factor (BAFF) (47) that stimulates B-cell activation and autoantibody production and eventual formation of immune complexes that can stimulate pDCs leading to further release of Type I IFN (48). IL-12 along with Type I IFNs stimulates both natural killer cells (innate) and Th1 cells (adaptive) that increase IFN $\gamma$ production and mediate tissue damage (49). In transgenic mouse model, increased IL-12 led to characteristic changes seen in pSS lung like lymphocytic infiltrates around the bronchi, intraluminal debris, increased cell proliferation in the alveoli, and increased interstitial and alveolar macrophages. This suggests that IL-12 is a key pathogenic cytokine in pSS lung (50).

Epithelial cells, upon TLR stimulation, also produce T-cell homeostatic cytokines, like IL-7, that is an important mediator of T-cell activation (51), IFN-gamma-mediated Th1 response (52) and maintenance of pathogenic Th17 cells (53). These infiltrating CD4+ T cells (Th1 and Th17) show an activated phenotype and release pro-inflammatory cytokines like IFN $\gamma$ (Type II IFN), IL-17 and IL-6. IFN $\gamma$ is involved in epithelial cell activation, apoptosis, inflammation, and tissue damage (54). IL17 has a pro-inflammatory effect on epithelial cells by induction of matrix metalloproteinases secretion, dysregulation of tight junction proteins, and support of ectopic lymphoid tissues (55). IL-6 promotes Th17 differentiation and is in turn important for the induction of IL-17 (55). CD4+ T cells also provide support to recruited B-cells, leading to further tissue damage. Subsequently, infiltrating T-cells organize with the B-cells to form germinal centers in affected tissue, a characteristic feature that is also seen in pulmonary pSS $(56,57)$.

Another evidence of lymphoproliferation in lung tissue comes from elevated beta-2-microglobulin that is released by lymphocytic tissue and elevated in serum from patients with pSS, particularly pulmonary pSS $(58,59)$. Lahdensuo and Korpela prospectively studied seventeen patients with pSS with no history of smoking to evaluate the correlation between pulmonary findings including chest CT and pulmonary function tests and serum beta-2-microglobulin as well as immunoglobulins including IgA, IgG, IgM. Interestingly they found nine patients with hyperinflation based on an elevated residual volume $(\mathrm{RV}) /$ total lung volume (TLC) ratio. Although, there was no significant differences between the serum immunoglobulins, when comparing patients with hyperinflation with those without, the mean level of serum beta-2 -microglobulin was significant elevated in patients with hyperinflation (60). The authors hypothesized that perhaps the elevation on beta-2microglobulin may reflect the severity of lymphoproliferation and that high levels may imply that obstructive small airway disease is associated with advance lymphoproliferative stage of the disease. Furthermore, Pertovaara and collaborators also evaluated the significance of baseline beta-2-microglobulin concentration as a risk factor for pulmonary involvement in 19 patients with pSS (61). They found that baseline elevated beta-2-microglobulin levels correlated with the development of subtle restrictive changes in pulmonary function test. Interestingly they also found an elevation of ESR, IgG, and protein concentrations suggesting an immunological activity in patients that had elevated beta-2-microglobulin and develop mild restrictive changes. 


\section{HISTOLOGY}

The pathology of Sjögren's lung disease varies with the location and type of involvement. Airway disease can be due to hyper-reactive airways, damage to the exocrine glands or due to cell infiltration and can affect trachea, bronchi, or bronchioles. Extraglandular mononuclear cell infiltration of bronchial and bronchiolar submucosa, largely comprising $\mathrm{CD} 4+\mathrm{T}$ cells, have been described in both large and small bronchi (16, 62, 63). Lymphocytic infiltrates have even been reported in broncheoalveolar lavages (BAL) from asymptomatic patients who have normal radiographs $(16,64)$. Bronchiolitis is the most common airway disease in pSS patients with frequency reported to be between 12 and $24 \%$ $(62,65)$. Different types of bronchiolitis have been identified with a majority being follicular bronchiolitis (66), which is characterized by hyperplastic lymphoid follicles with a reactive germinal center that is distributed along the bronchovascular bundles $(7,67)$. Other bronchiolitis, like chronic bronchiolitis, obliterative bronchiolitis, and panbronchiolitis have also been reported (66) and present with a spectrum of histological changes indistinguishable from other etiologies like lymphocytic infiltration of small airways, bronchiolar smooth muscle hypertrophy, obstruction of bronchioles with mucus or even complete obliteration of bronchioles with scarring.

Among the ILDs seen in patients with pSS, non-specific interstitial pneumonitis (NSIP) is the most frequent pathological subtype and has been reported to be present in up to $45 \%$ of histopathology available from patients $(11,64,65,68,69)$. NSIP usually presents on histology with varying interstitial inflammation and fibrosis with preserved lung architecture (7, 70). BALs have also shown lymphocytic alveolitis in pSS patients (64). Interestingly pSS patients who have autoantibodies to SSA, a key autoantigen in pSS, have higher risk of developing ILD $(71,72)$. Although, one recent study did not find that association, with similar antibody levels in patients with or without anti-SSA antibodies (69). Additionally, patients with lymphocytic alveolitis have increased gammaglobulins, and an increased prevalence of rheumatoid factor and antinuclear antibody (ANA). Areas of interstitial fibrosis in patients with NSIP may result in traction bronchiectasis due to enlarged air spaces resulting in a CT pattern which helps distinguish it from usual interstitial pneumonia (7).

Usual interstitial pneumonia (UIP) is another type of ILD reported in up to $16-33 \%$ of pSS patients with ILD $(11,69,70)$. Similar to UIP in other diseases, it is characterized by honeycombing on lung biopsy with histopathological findings of sub-pleural and peripheral lesions, patchy interstitial fibrosis, scattered fibroblast foci, and mild interstitial inflammation with patchy alveolar infiltrates of lymphocytes, plasma cells and lymphoid follicles with germinal centers (57). Another type of ILD reported in pSS patients is lymphocytic interstitial pneumonitis (LIP) accounting for about $15 \%$ of ILD lesions in this disease $(11,69)$. It shows diffuse abundance of polyclonal lymphocytes and plasma cells in the pulmonary parenchyma with lymphoid follicles and even germinal centers. Organizing pneumonitis is another ILD reported in up to $7 \%$ of patients with histological findings similar to other etiologies with patchy involvement of pulmonary parenchyma by fibromyxoid plugs of granulation tissue with sub-pleural or peri-bronchovascular distribution (11).

Patients with Sjögren's syndrome have an increased risk of non-Hodgkin lymphoma, specifically marginal zone B-cell lymphoma, and mucosa associated lymphoid tissue (MALT) lymphoma $(73,74)$. Primary pulmonary lymphoma, also known as bronchial-associated lymphoid tissue (BALT) lymphoma has been reported in $1-2 \%$ of patients with pSS (75). There is no organized lymphoid tissue in the normal pulmonary parenchyma but inflammatory conditions such as pSS and chronic exposure to various antigenic stimuli can lead to lymphocytic hyperplasia which may transform into a BALT lymphoma $(76,77)$. These lymphoma originate from marginal zone and are characterized by infiltrate of lymphoepithelial cells invading bronchial epithelial tissues (77). These are usually negative for infectious agents like human herpesvirus-6 or Epstein-Barr virus. Other lung findings reported, however rare, are pulmonary amyloidosis, pulmonary embolism and pulmonary hypertension.

\section{CLINICAL MANIFESTATIONS}

Clinical manifestations in pSS can be non-specific and patients can present with dyspnea (62\%), cough (54\%), sputum production (14\%), chest pain (11\%), and/or fever (7\%). Nearly three fourth of patients have positive anti-Ro/SSa and one third have anti-La/SS-B antibodies (11). Interesting, in a subset of patients, pulmonary involvement can be the initial manifestation of the disease and can even precede the diagnosis. In a prospective study that included 77 newly diagnosed pSS patients, 13 patients $(16.8 \%)$ presented with ILD as the first presenting symptom (78).

Both large and small airways, and lung parenchyma can be affected in pSS. Patients can also have lymphoproliferative disorders as well as other abnormalities such as cystic lesions. These lesions can exist in isolation or coexist in the same patient. The prognosis of Sjögren's lung disease varies on the type of pulmonary involvement. Cystic lesions are usually associated with good survival and few complications as compared with ILD or lymphoid interstitial pneumonia that carries a poor prognosis in terms of not only survival but also quality of life.

\section{Airway Disease in pSS}

Small airway disease is the most commonly recognized pulmonary disorder among symptomatic pSS (79). Airway involvement can include bronchiectasis, bronchiolitis, and hyper-reactive airways. The prevalence of bronchiectasis in pSS is up to $10 \%$ with common involvement of the inferior lobes (Figure 2). Patients with bronchiectasis are generally older at diagnosis of pSS and have a greater frequency of hiatal hernia when compared to controls. Additionally, patients with bronchiectasis have a lower prevalence of anti-Ro/SSA antibodies but increased presence of anti-smooth muscle antibodies (anti-SMA) (80). Clinical symptoms are variable and can be non-specific; for example, patients can complain of dry 


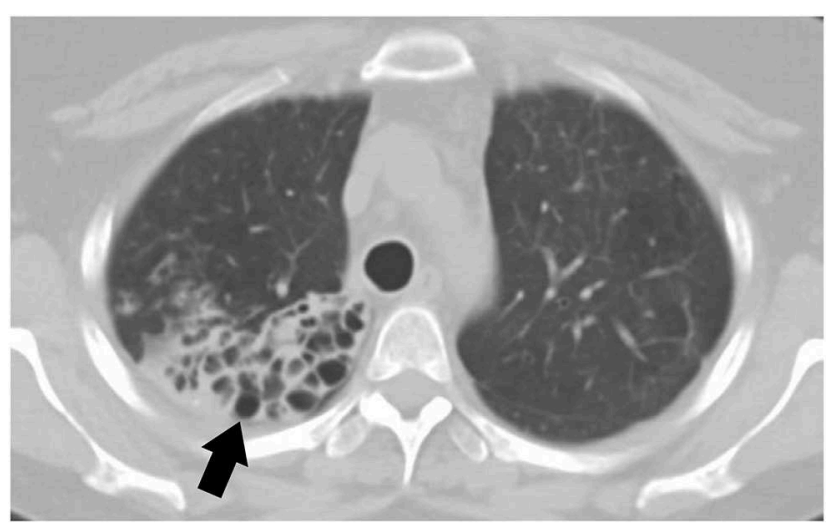

FIGURE 2 | CT scan of a 44-year-old female with primary Sjögren's syndrome demonstrating bronchiectasis on the right lower lobe.

cough, or isolated dyspnea. In rare occasions patients can also have hemoptysis likely due to exacerbation of bronchiectasis. Patients with bronchiectasis also had increased respiratory infections and pneumonia (80).

Hyper-reactive airway is a common presentation of airway involvement in pSS. A small study where 15 patients were followed prospectively found a decline in pulmonary function test (PFT) parameters like diffusion capacity (DLCO), total lung volume (TLC), forced vital capacity (FVC), functional residual capacity $(\mathrm{FRC})$, and expiratory midflows $\left(\mathrm{FEF}_{50}\right)$ demonstrating distal airway involvement in those patients (81).

Chronic obstructive pulmonary disease (COPD) is common in patients pSS, including patients with no previous history of smoking (82). This was demonstrated in a study of 51 patients with pSS from which $30 \%$ of patients with pSS that never smoked fulfilled the global initiative for chronic obstructive lung disease criteria for COPD (83). Another study that included 41 female patients with pSS also demonstrated a high incidence of COPD in this particular population. Patients had a baseline pulmonary function test as well as high resolution chest CT scan and were followed prospectively for 11 years. At baseline, 7\% of pSS patients were diagnosed with definite or suspected COPD. At follow-up, 37\% of pSS patients fulfilled COPD criteria (84).

\section{Interstitial Lung Disease}

The main symptoms of patients with ILD are cough and shortness of breath. It appears to be more frequently associated with positive anti-SSA, low levels of $\mathrm{C} 3$, elevated rheumatoid factor and C-reactive protein $(69,71,72)$. Interstitial lung disease can also be present in different patterns with the most common being NSIP (33\%), followed by UIP (23.8\%), and LIP (9.5\%) (69, $85)$. Interestingly, patients with ILD have more Raynaud's and gastrointestinal manifestations as compared with patients with pSS and no ILD. When compared to UIP patients with idiopathic pulmonary fibrosis (IPF), pSS patients with UIP tend to be older, predominately female, with enlarged mediastinal lymph nodes and bronchial thickening on HRCT. Reassuringly, pSS patients with UIP tend to have a better response to immunotherapy and thus a better prognosis as compared to patients with IPF (57).
TABLE 1 | Definition of pulmonary involvement in pSS by EULAR-SS Task Force.

\begin{tabular}{lll}
\hline Low & Moderate & Severe \\
\hline Dry cough (-) Imaging & $>70 \%$ DLCO $>40 \%$ & DLCO $<40 \%$ \\
Asymptomatic & $80 \%<$ FVC $>60 \%$ & FVC $<60 \%$ \\
& ILD by Chest CT & ILD by Chest CT + NYHA III-IV
\end{tabular}

\section{Cystic Lung Disease}

Cystic lung disease has been noted in up to $20 \%$ of patients with Sjögren's syndrome. Cysts are mostly bilateral, with the majority located in the middle lung area, and have a benign course. The majority of the patients have no symptoms and do not develop a specific lung disease or lymphoproliferative disorder. Sjögren's patients with cystic lung disease tend to have increased prevalence of anti-SSB antibodies (86).

\section{Pulmonary Lymphoma}

Different types of lymphomas have been associated with pSS including non-Hodgkin's lymphoma (NHL), marginal zone B cell lymphoma, and mucosa associated lymphoid tissue (MALT) that can present with symptoms of cough and slowly progressive dyspnea (75).

\section{Lymphocytic Interstitial Pneumonitis (LIP)}

Common symptoms in LIP include cough and dyspnea, and physical findings can include coarse basal crackles. The clinical course is variable from complete resolution without treatment to progression and possible death or transformation to lymphoma (87).

\section{EVALUATION}

The European League Against Rheumatism (EULAR) - Sjögren's Syndrome (EULAR-SS) task force defined lung involvement in pSS based on a combination of three different parameters: clinical symptoms, pulmonary function test findings, and high-resolution chest computer tomography abnormalities. For example, EULAR SS Disease Activity Index (ESSDAI) considers pulmonary involvement in a patient with respiratory symptoms and normal radiology findings or patients with no symptoms but abnormal imaging or PFT's. The level of lung disease activity has been defined as low, moderate, or high (11) (Table 1). Symptomatic patients should be further evaluated for airway and parenchymal involvement with pulmonary function test as well as high resolution CT scan.

\section{MANAGEMENT}

Treatment of pulmonary manifestation in pSS depends on the type of involvement. Patients with bronchiectasis can be treated with nebulized hypertonic saline to help with the secretion, as well as bronchodilator, as needed. Isotonic saline can help improve throat dryness seen in patients with pSS as well as 
voice production (88). On the other hand, treatment with antiinflammatory medications have not been proven successful in treating patients with hyper-reactive airways (89).

Corticosteroids and other immunosuppressants such as azathioprine, mycophenolate, and cyclophosphamide have been studied in ILD due to connective tissue diseases and shown to have modest benefit $(72,90-94)$. However, these studies have very small numbers of patients with pSS; there still are no large clinical trials evaluating the effectiveness of immunosuppression in the treatment of pSS patients with ILD. Rituximab, a chimeric monoclonal antibody that binds to cell surface protein CD20 that is primarily and widely expressed on B-cells and triggers B-cell death, was evaluated for ILD treatment in one small openlabel study of 10 patients. The patients were followed for 6 months after rituximab treatment and reported to have some improvement on the DLCO, fatigue, shortness of breath, or cough, as well as CT findings. This is a promising study that will need to be repeated with more patients and longer follow-up (95). LIP may respond to corticosteroids although the response is unpredictable.

With the critical role of BAFF and B-cells in the pathogenesis of pSS, targeting this molecule in pulmonary pSS using belimumab, an FDA approved anti-BAFF monoclonal antibody, may be beneficial. Additionally, targeting $\mathrm{B}$-cells with a combination of rituximab and belimumab is currently being explored for pSS and may be considered for patients with severe lung involvement (trial NCT02631538).

Targeting T-cells by using abatacept, a CTLA- 4 monoclonal that modulated T-cell co-stimulation, has shown some benefit in pSS with decrease in lymphocytic foci, reduction in local Tcells and gammaglobulins, and could be beneficial in pulmonary pSS (96).

Direct inhibition of inflammatory cytokines may be of potential benefit in pulmonary pSS too. IL-17 has been shown to play an important role in pathogenesis of pSS and can be targeted with monoclonal antibodies like secukinumab $(97,98)$ and ilxekizumab $(99)$ that are already approved for psoriasis and psoriatic arthritis. IL-6, another pro-inflammatory cytokine attributable to pulmonary pSS, may also be of interest and RCTs looking at its role in pSS are currently ongoing (trial NCT01782235).

With the key role of IFNs in the pathogenesis of pSS, targeting them may be beneficial in pulmonary pSS. Anifrolumab is a monoclonal blocking type I IFN receptor (IFNAR1) currently being evaluated in SLE (100) and could be a potential agent for use in pulmonary pSS. Additionally, blocking downstream signaling of IFN and other pro-inflammatory cytokines signaling

\section{REFERENCES}

1. Shiboski CH, Shiboski SC, Seror R, Criswell LA, Labetoulle M, Lietman TM, et al. 2016 american college of rheumatology/european league against rheumatism classification criteria for primary Sjögren's syndrome: a consensus and data-driven methodology involving three international patient cohorts. Arthritis Rheumatol. (2017) 69:35-45. doi: 10.1002/art.39859 through use of janus kinase (JAK) inhibitors, the so called JAKinibs, may have wider benefit. Recent evidence suggests it may also influence BAFF signaling, thus modulating B cell responses (101). JAKinibs like tofacitinib have been recently approved for use for rheumatoid arthritis, psoriatic arthritis, and ulcerative colitis, and are being explored in SLE and pSS (102). There is some evidence that JAKinibs may be of benefit in chronic obstructive pulmonary disease (103) and idiopathic pulmonary fibrosis (104). It would be important to explore their role in pulmonary pSS.

\section{CONCLUSION}

Pulmonary involvement in pSS is a prevalent, yet underexplored, clinical entity. Clinical manifestations are varied and can present with airway or lung parenchymal involvement. Accordingly, initial symptoms can be vague and non-specific. Histologic evidence suggests a common pathway that leads to glandular and lung pathogenesis with a key role played by epithelial cells. Patients with pSS should be systematically evaluated for pulmonary involvement and managed according to their presentation. Larger, systematic, randomized clinical trials are needed to evaluate various aspects of immunosuppression in pulmonary pSS. Based on our understanding of the biology of the disease, drugs targeting B-cells, like rituximab (antiCD20) or belimumab (anti-BAFF); or those targeting Tcells, like abatacept (CTLA-4 Ig), could be beneficial. Direct targeting of pro-inflammatory cytokines like IL-17, IL-6, and Type I IFNs could also be beneficial. Additionally, smallmolecules that block JAK signaling may offer a wider beneficial effect.

\section{AUTHOR CONTRIBUTIONS}

SH: concept, review, edit and supervision. SG and MF: draft and revisions. Both SG and MF contributed equally to the draft.

\section{FUNDING}

This research was supported by the Intramural Research Program of the National Institute of Arthritis and Musculoskeletal and Skin Diseases of the National Institutes of Health.

\section{ACKNOWLEDGMENTS}

We would like to thank Cindy Clark, NIH Library Editing Service, for reviewing the manuscript. 
4. Maciel G, Crowson CS, Matteson EL, Cornec D. Prevalence of primary Sjögren's syndrome in a US population-based cohort. Arthritis Care Res. (2017) 69:1612-6. doi: 10.1002/acr.23173

5. Anaya JM, Rojas-Villarraga A, Mantilla RD, Arcos-Burgos M, SarmientoMonroy JC. Polyautoimmunity in Sjögren syndrome. Rheum Dis Clin North Am. (2016) 42:457-72. doi: 10.1016/j.rdc.2016.03.005

6. Psianou K, Panagoulias I, Papanastasiou AD, de Lastic AL, Rodi M, Spantidea PI, et al. Clinical and immunological parameters of Sjögren's syndrome. Autoimmun Rev. (2018) 17:1053-64. doi: 10.1016/j.autrev.2018.05.005

7. Flament T, Bigot A, Chaigne B, Henique H, Diot E, Marchand-Adam S. Pulmonary manifestations of Sjögren's syndrome. Eur Respir Rev. (2016) 25:110-23. doi: 10.1183/16000617.0011-2016

8. Palm O, Garen T, Berge Enger T, Jensen JL, Lund MB, Aalokken TM, et al. Clinical pulmonary involvement in primary Sjögren's syndrome: prevalence, quality of life and mortality-a retrospective study based on registry data. Rheumatology. (2013) 52:173-9. doi: 10.1093/rheumatology/kes311

9. Kim HJ, Kim KH, Hann HJ, Han S, Kim Y, Lee SH, et al. Incidence, mortality, and causes of death in physician-diagnosed primary Sjögren's syndrome in Korea: a nationwide, population-based study. Semin Arthritis Rheum. (2017) 47:222-7. doi: 10.1016/j.semarthrit.2017.03.004

10. Fauchais AL, Martel C, Gondran G, Lambert M, Launay D, Jauberteau $\mathrm{MO}$, et al. Immunological profile in primary Sjögren syndrome: clinical significance, prognosis and long-term evolution to other auto-immune disease. Autoimmun Rev. (2010) 9:595-9. doi: 10.1016/j.autrev.2010.05.004

11. Ramos-Casals M, Brito-Zeron P, Seror R, Bootsma H, Bowman SJ, Dorner T, et al. Characterization of systemic disease in primary Sjögren's syndrome: EULAR-SS Task Force recommendations for articular, cutaneous, pulmonary and renal involvements. Rheumatology. (2015) 54:2230-8. doi: 10.1093/rheumatology/kev200

12. Flores-Chavez A, Kostov B, Solans R, Fraile G, Maure B, Feijoo-Masso C, et al. Severe, life-threatening phenotype of primary Sjögren's syndrome: clinical characterisation and outcomes in 1580 patients (GEAS-SS Registry). Clin Exp Rheumatol. (2018) 36 (Suppl. 112):121-9.

13. Kelly C, Gardiner P, Pal B, Griffiths I. Lung function in primary Sjögren's syndrome: a cross sectional and longitudinal study. Thorax. (1991) 46:180-3. doi: $10.1136 /$ thx. 46.3 .180

14. Matsuyama N, Ashizawa K, Okimoto T, Kadota J, Amano H, Hayashi K. Pulmonary lesions associated with Sjögren's syndrome: radiographic and CT findings. Br J Radiol. (2003) 76:880-4. doi: 10.1259/bjr/18937619

15. Nannini C, Jebakumar AJ, Crowson CS, Ryu JH, Matteson EL. Primary Sjögren's syndrome 1976-2005 and associated interstitial lung disease: a population-based study of incidence and mortality. BMJ Open. (2013) 3:e003569. doi: 10.1136/bmjopen-2013-003569

16. Papiris SA, Saetta M, Turato G, La Corte R, Trevisani L, Mapp CE, et al. CD4-positive T-lymphocytes infiltrate the bronchial mucosa of patients with Sjögren's syndrome. Am J Respir Crit Care Med. (1997) 156:637-41. doi: 10.1164/ajrccm.156.2.9610076

17. Wang J, Wen Y, Zhou M, Shi X, Jiang L, Li M, et al. Ectopic germinal center and megalin defect in primary Sjögren syndrome with renal Fanconi syndrome. Arthritis Res Ther. (2017) 19:120. doi: 10.1186/s13075-017-1317-x

18. Jasiek M, Karras A, Le Guern V, Krastinova E, Mesbah R, Faguer $\mathrm{S}$, et al. A multicentre study of 95 biopsy-proven cases of renal disease in primary Sjögren's syndrome. Rheumatology. (2017) 56:362-70. doi: 10.1093/rheumatology/kew376

19. Francois H, Mariette X. Renal involvement in primary Sjögren syndrome. Nat Rev Nephrol. (2016) 12:82-93. doi: 10.1038/nrneph.2015.174

20. Skopouli FN, Barbatis C, Moutsopoulos HM. Liver involvement in primary Sjögren's syndrome. Br J Rheumatol. (1994) 33:745-8. doi: 10.1093/rheumatology/33.8.745

21. Kakugawa T, Sakamoto N, Ishimoto H, Shimizu T, Nakamura H, Nawata A, et al. Lymphocytic focus score is positively related to airway and interstitial lung diseases in primary Sjögren's syndrome. Respir Med. (2018) 137:95-102. doi: 10.1016/j.rmed.2018.02.023

22. Brkic Z, Maria NI, van Helden-Meeuwsen CG, van de Merwe JP, van Daele PL, Dalm VA, et al. Prevalence of interferon type I signature in CD14 monocytes of patients with Sjögren's syndrome and association with disease activity and BAFF gene expression. Ann Rheum Dis. (2013) 72:728-35. doi: 10.1136/annrheumdis-2012-201381
23. Christodoulou MI, Kapsogeorgou EK, Moutsopoulos NM, Moutsopoulos HM. Foxp3+ T-regulatory cells in Sjögren's syndrome: correlation with the grade of the autoimmune lesion and certain adverse prognostic factors. Am J Pathol. (2008) 173:1389-96. doi: 10.2353/ajpath.2008.080246

24. Katsifis GE, Rekka S, Moutsopoulos NM, Pillemer S, Wahl SM. Systemic and local interleukin-17 and linked cytokines associated with Sjögren's syndrome immunopathogenesis. Am J Pathol. (2009) 175:1167-77. doi: 10.2353/ajpath.2009.090319

25. Theander E, Vasaitis L, Baecklund E, Nordmark G, Warfvinge G, Liedholm $\mathrm{R}$, et al. Lymphoid organisation in labial salivary gland biopsies is a possible predictor for the development of malignant lymphoma in primary Sjögren's syndrome. Ann Rheum Dis. (2011) 70:1363-8. doi: 10.1136/ard.2010.144782

26. Moutsopoulos HM, Kordossis T. Sjögren's syndrome revisited: autoimmune epithelitis. $\mathrm{Br} J$ Rheumatol. (1996) 35:204-6. doi: 10.1093/rheumatology/35.3.204

27. Routsias JG, Tzioufas AG. Sjögren's syndrome-study of autoantigens and autoantibodies. Clin Rev Allergy Immunol. (2007) 32:238-51. doi: 10.1007/s12016-007-8003-8

28. Wang F, Jackson MW, Maughan V, Cavill D, Smith AJ, Waterman SA, et al. Passive transfer of Sjögren's syndrome IgG produces the pathophysiology of overactive bladder. Arthritis Rheum. (2004) 50:3637-45. doi: 10.1002/art.20625

29. Lucchesi D, Pitzalis C, Bombardieri M. EBV and other viruses as triggers of tertiary lymphoid structures in primary Sjögren's syndrome. Exp Rev Clin Immunol. (2014) 10:445-55. doi: 10.1586/1744666X.2014.892417

30. Lugonja B, Yeo L, Milward MR, Smith D, Dietrich T, Chapple IL, et al. Periodontitis prevalence and serum antibody reactivity to periodontal bacteria in primary Sjögren's syndrome: a pilot study. J Clin Periodontol. (2016) 43:26-33. doi: 10.1111/jcpe.12485

31. Hida A, Imaizumi M, Sera N, Akahoshi M, Soda M, Maeda R, et al. Association of human T lymphotropic virus type I with Sjögren syndrome. Ann Rheum Dis. (2010) 69:2056-7. doi: 10.1136/ard.2010.128736

32. Terada K, Katamine S, Eguchi K, Moriuchi R, Kita M, Shimada H, et al. Prevalence of serum and salivary antibodies to HTLV-1 in Sjögren's syndrome. Lancet. (1994) 344:1116-9. doi: 10.1016/S0140-6736(94)90630-0

33. Yamashiro T, Kamiya H, Miyara T, Gibo S, Ogawa K, Akamine T, et al. CT scans of the chest in carriers of human T-cell lymphotropic virus type 1: presence of interstitial pneumonia. Acad Radiol. (2012) 19:952-7. doi: 10.1016/j.acra.2012.03.020

34. Okada F, Ando Y, Yoshitake S, Yotsumoto S, Matsumoto S, Wakisaka M, et al. Pulmonary CT findings in 320 carriers of human T-lymphotropic virus type 1. Radiology. (2006) 240:559-64. doi: 10.1148/radiol.24020 50886

35. Kadota J, Mukae H, Fujii T, Seki M, Tomono K, Kohno S. Clinical similarities and differences between human T-cell lymphotropic virus type 1-associated bronchiolitis and diffuse panbronchiolitis. Chest. (2004) 125:1239-47. doi: 10.1378/chest.125.4.1239

36. Yamazato Y, Miyazato A, Kawakami K, Yara S, Kaneshima H, Saito A. High expression of $\mathrm{p} 40(\operatorname{tax})$ and pro-inflammatory cytokines and chemokines in the lungs of human T-lymphotropic virus type 1-related bronchopulmonary disorders. Chest. (2003) 124:2283-92. doi: 10.1378/chest.124.6.2283

37. Carreto-Binaghi LE, Aliouat el M, Taylor ML. Surfactant proteins, SP-A and SP-D, in respiratory fungal infections: their role in the inflammatory response. Respir Res. (2016) 17:66. doi: 10.1186/s12931-016-0385-9

38. Kishore U, Greenhough TJ, Waters P, Shrive AK, Ghai R, Kamran MF, et al. Surfactant proteins SP-A and SP-D: structure, function and receptors. $\mathrm{Mol}$ Immunol. (2006) 43:1293-315. doi: 10.1016/j.molimm.2005.08.004

39. Soto-Cardenas MJ, Gandia M, Brito-Zeron P, Arias MT, Armiger N, Bove $A$, et al. Etiopathogenic role of surfactant protein $\mathrm{d}$ in the clinical and immunological expression of primary Sjögren syndrome. J Rheumatol. (2015) 42:111-8. doi: 10.3899/jrheum.140394

40. Kapsogeorgou EK, Abu-Helu RF, Moutsopoulos HM, Manoussakis MN. Salivary gland epithelial cell exosomes: a source of autoantigenic ribonucleoproteins. Arthritis Rheum. (2005) 52:1517-21. doi: 10.1002/art.21005

41. Ohlsson M, Jonsson R, Brokstad KA. Subcellular redistribution and surface exposure of the Ro52, Ro60 and La48 autoantigens during apoptosis in human ductal epithelial cells: a possible mechanism in the 
pathogenesis of Sjögren's syndrome. Scand J Immunol. (2002) 56:456-69. doi: 10.1046/j.1365-3083.2002.01072_79.x

42. Yang $\mathrm{T}$, Zeng $\mathrm{H}$, Zhang J, Okamoto CT, Warren DW, Wood RL, et al. MHC class II molecules, cathepsins, and La/SSB proteins in lacrimal acinar cell endomembranes. Am J Physiol. (1999) 277:C994-1007. doi: 10.1152/ajpcell.1999.277.5.C994

43. Kyriakidis NC, Kapsogeorgou EK, Gourzi VC, Konsta OD, Baltatzis GE, Tzioufas AG. Toll-like receptor 3 stimulation promotes Ro52/TRIM21 synthesis and nuclear redistribution in salivary gland epithelial cells, partially via type I interferon pathway. Clin Exp Immunol. (2014) 178:548-60. doi: $10.1111 /$ cei.12432

44. Kawakami A, Nakashima K, Tamai M, Nakamura H, Iwanaga N, Fujikawa $\mathrm{K}$, et al. Toll-like receptor in salivary glands from patients with Sjögren's syndrome: functional analysis by human salivary gland cell line. J Rheumatol. (2007) 34:1019-26.

45. Campos J, Hillen MR, Barone F. Salivary gland pathology in Sjögren's syndrome. Rheum Dis Clin North Am. (2016) 42:473-83. doi: 10.1016/j.rdc.2016.03.006

46. Gottenberg JE, Cagnard N, Lucchesi C, Letourneur F, Mistou S, Lazure $\mathrm{T}$, et al. Activation of IFN pathways and plasmacytoid dendritic cell recruitment in target organs of primary Sjögren's syndrome. Proc Natl Acad Sci USA. (2006) 103:2770-5. doi: 10.1073/pnas.051083 7103

47. Ittah M, Miceli-Richard C, Gottenberg JE, Sellam J, Eid P, Lebon $\mathrm{P}$, et al. Viruses induce high expression of BAFF by salivary gland epithelial cells through TLR- and type-I IFN-dependent and -independent pathways. Eur J Immunol. (2008) 38:1058-64. doi: 10.1002/eji.20073 8013

48. Wildenberg ME, van Helden-Meeuwsen CG, van de Merwe JP, Drexhage HA, Versnel MA. Systemic increase in type I interferon activity in Sjögren's syndrome: a putative role for plasmacytoid dendritic cells. Eur J Immunol. (2008) 38:2024-33. doi: 10.1002/eji.200738008

49. Nocturne G, Mariette X. Advances in understanding the pathogenesis of primary Sjögren's syndrome. Nat Rev Rheumatol. (2013) 9:544-56. doi: 10.1038/nrrheum.2013.110

50. McGrath-Morrow S, Laube B, Tzou SC, Cho C, Cleary J, Kimura H, et al. IL-12 overexpression in mice as a model for Sjögren lung disease. Am J Physiol Lung Cell Mol Physiol. (2006) 291:L837-46. doi: 10.1152/ajplung.0013 4.2006

51. Bikker A, van Woerkom JM, Kruize AA, Wenting-van Wijk M, de Jager W, Bijlsma JW, et al. Increased expression of interleukin-7 in labial salivary glands of patients with primary Sjögren's syndrome correlates with increased inflammation. Arthritis Rheum. (2010) 62:969-77. doi: 10.1002/art.2 7318

52. Jin JO, Kawai $\mathrm{T}$, Cha $\mathrm{S}, \mathrm{Yu}$ Q. Interleukin-7 enhances the Th1 response to promote the development of Sjögren's syndrome-like autoimmune exocrinopathy in mice. Arthritis Rheum. (2013) 65:2132-42. doi: 10.1002/art.38007

53. Chen Y, Chauhan SK, Tan X, Dana R. Interleukin-7 and-15 maintain pathogenic memory Th17 cells in autoimmunity. J Autoimmun. (2017) 77:96-103. doi: 10.1016/j.jaut.2016.11.003

54. Abu-Helu RF, Dimitriou ID, Kapsogeorgou EK, Moutsopoulos $\mathrm{HM}$, Manoussakis MN. Induction of salivary gland epithelial cell injury in Sjögren's syndrome: in vitro assessment of $\mathrm{T}$ cell-derived cytokines and Fas protein expression. J Autoimmun. (2001) 17:141-53. doi: 10.1006/jaut.2001.0524

55. Verstappen GM, Corneth OBJ, Bootsma H, Kroese FGM. Th17 cells in primary Sjögren's syndrome: pathogenicity and plasticity. J Autoimmun. (2018) 87:16-25. doi: 10.1016/j.jaut.2017.11.003

56. Salomonsson S, Jonsson MV, Skarstein K, Brokstad KA, Hjelmstrom $\mathrm{P}$, Wahren-Herlenius $\mathrm{M}$, et al. Cellular basis of ectopic germinal center formation and autoantibody production in the target organ of patients with Sjögren's syndrome. Arthritis Rheum. (2003) 48:3187-201. doi: $10.1002 /$ art.11311

57. Enomoto Y, Takemura T, Hagiwara E, Iwasawa T, Okudela K, Yanagawa $\mathrm{N}$, et al. Features of usual interstitial pneumonia in patients with primary Sjögrens syndrome compared with idiopathic pulmonary fibrosis. Respir Investig. (2014) 52:227-35. doi: 10.1016/j.resinv.2014.02.003
58. Krejsek J, Slezak R, Kopecky O, Derner V, Andrys C. Elevation of serum soluble intercellular adhesion molecule-1 (sICAM-1) and beta-2microglobulin in Sjögren's syndrome. Clin Rheumatol. (1997) 16:149-53 doi: 10.1007/BF02247843

59. Michalski JP, Daniels TE, Talal N, Grey HM. Beta2 microglobulin and lymphocytic infiltration in Sjögren's syndrome. N Engl J Med. (1975) 293:1228-31. doi: 10.1056/NEJM197512112932404

60. Lahdensuo A, Korpela M. Pulmonary findings in patients with primary Sjögren's syndrome. Chest. (1995) 108:316-9. doi: 10.1378/chest.108.2.316

61. Pertovaara M, Korpela M, Saarelainen S, Laitinen J, Jarvenpaa R, Laippala $\mathrm{P}$, et al. Long-term follow-up study of pulmonary findings in patients with primary Sjögren's syndrome. Scand J Rheumatol. (2004) 33:343-8. doi: 10.1080/03009740410006196

62. Papiris SA, Maniati M, Constantopoulos SH, Roussos C, Moutsopoulos HM, Skopouli FN. Lung involvement in primary Sjögren's syndrome is mainly related to the small airway disease. Ann Rheum Dis. (1999) 58:61-4. doi: $10.1136 /$ ard.58.1.61

63. Gardiner P, Ward C, Allison A, Ashcroft T, Simpson W, Walters H, et al. Pleuropulmonary abnormalities in primary Sjögren's syndrome. $J$ Rheumatol. (1993) 20:831-7.

64. Hatron PY, Wallaert B, Gosset D, Tonnel AB, Gosselin B, Voisin C, et al. Subclinical lung inflammation in primary Sjögren's syndrome. relationship between bronchoalveolar lavage cellular analysis findings and characteristics of the disease. Arthritis Rheum. (1987) 30:1226-31. doi: $10.1002 /$ art.1780301104

65. Ito I, Nagai S, Kitaichi M, Nicholson AG, Johkoh T, Noma $S$, et al. Pulmonary manifestations of primary Sjögren's syndrome: a clinical, radiologic, and pathologic study. Am J Respir Crit Care Med. (2005) 171:6328. doi: 10.1164/rccm.200403-417OC

66. Shi JH, Liu HR, Xu WB, Feng RE, Zhang ZH, Tian XL, et al. Pulmonary manifestations of Sjögren's syndrome. Respiration. (2009) 78:377-86. doi: $10.1159 / 000214841$

67. Ryu JH, Myers JL, Swensen SJ. Bronchiolar disorders. Am J Respir Crit Care Med. (2003) 168:1277-92. doi: 10.1164/rccm.200301-053SO

68. Reina D, Roig Vilaseca D, Torrente-Segarra V, Cerda D, Castellvi I, Diaz Torne C, et al. Sjögren's syndrome-associated interstitial lung disease: a multicenter study. Reumatol Clin. (2016) 12:201-5. doi: 10.1016/j.reuma.2015.09.003

69. Gao H, Zhang XW, He J, Zhang J, An Y, Sun Y, et al. Prevalence, risk factors, and prognosis of interstitial lung disease in a large cohort of Chinese primary Sjögren syndrome patients: a case-control study. Medicine. (2018) 97:e11003. doi: 10.1097/MD.0000000000011003

70. Enomoto Y, Takemura T, Hagiwara E, Iwasawa T, Fukuda Y, Yanagawa N, et al. Prognostic factors in interstitial lung disease associated with primary Sjögren's syndrome: a retrospective analysis of 33 pathologically-proven cases. PLoS ONE. (2013) 8:e73774. doi: 10.1371/journal.pone.0073774

71. Li X, Xu B, Ma Y, Li X, Cheng Q, Wang X, et al. Clinical and laboratory profiles of primary Sjögren's syndrome in a Chinese population: a retrospective analysis of 315 patients. Int J Rheum Dis. (2015) 18:439-46. doi: 10.1111/1756-185X.12583

72. Parambil JG, Myers JL, Lindell RM, Matteson EL, Ryu JH. Interstitial lung disease in primary Sjögren syndrome. Chest. (2006) 130:1489-95. doi: $10.1378 /$ chest.130.5.1489

73. Kauppi M, Pukkala E, Isomaki H. Elevated incidence of hematologic malignancies in patients with Sjögren's syndrome compared with patients with rheumatoid arthritis (Finland). Cancer Causes Control. (1997) 8:201-4. doi: 10.1023/A:1018472213872

74. Theander E, Henriksson G, Ljungberg O, Mandl T, Manthorpe R, Jacobsson LT. Lymphoma and other malignancies in primary Sjögren's syndrome: a cohort study on cancer incidence and lymphoma predictors. Ann Rheum Dis. (2006) 65:796-803. doi: 10.1136/ard.2005.041186

75. Hansen LA, Prakash UB, Colby TV. Pulmonary lymphoma in Sjögren's syndrome. Mayo Clin Proc. (1989) 64:920-31. doi: 10.1016/S0025-6196(12)61219-1

76. Imai $\mathrm{H}$, Sunaga $\mathrm{N}$, Kaira $\mathrm{K}$, Kawashima O, Yanagitani $\mathrm{N}$, Sato $\mathrm{K}$, et al. Clinicopathological features of patients with bronchialassociated lymphoid tissue lymphoma. Intern Med. (2009) 48:301-6. doi: 10.2169/internalmedicine.48.1438 
77. Ingegnoli F, Sciascera A, Galbiati V, Corbelli V, D’Ingianna E, Fantini F. Bronchus-associated lymphoid tissue lymphoma in a patient with primary Sjögren's syndrome. Rheumatol Int. (2008) 29:207-9. doi: 10.1007/s00296-008-0645-1

78. Manfredi A, Sebastiani M, Cerri S, Cassone G, Bellini P, Casa GD, et al. Prevalence and characterization of non-sicca onset primary Sjögren syndrome with interstitial lung involvement. Clin Rheumatol. (2017) 36:1261-8. doi: 10.1007/s10067-017-3601-1

79. Kampolis CF, Fragkioudaki S, Mavragani CP, Zormpala A, Samakovli A, Moutsopoulos HM. Prevalence and spectrum of symptomatic pulmonary involvement in primary Sjögren's syndrome. Clin Exp Rheumatol. (2018) 36 (Suppl. 112):94-101.

80. Soto-Cardenas MJ, Perez-De-Lis M, Bove A, Navarro C, Brito-Zeron P, DiazLagares C, et al. Bronchiectasis in primary Sjögren's syndrome: prevalence and clinical significance. Clin Exp Rheumatol. (2010) 28:647-53.

81. Ludviksdottir D, Valtysdottir ST, Hedenstrom H, Hallgren R, Gudbjornsson B. Eight-year follow-up of airway hyperresponsiveness in patients with primary Sjögren's syndrome. Ups J Med Sci. (2017) 122:51-5. doi: 10.1080/03009734.2016.1239663

82. Linstow M, Kriegbaum NJ, Backer V, Ulrik C, Oxholm P. A follow-up study of pulmonary function in patients with primary Sjögren's syndrome. Rheumatol Int. (1990) 10:47-9. doi: 10.1007/BF02274782

83. Nilsson AM, Diaz S, Theander E, Hesselstrand R, Piitulainen E, Ekberg O, et al. Chronic obstructive pulmonary disease is common in never-smoking patients with primary Sjögren syndrome. J Rheumatol. (2015) 42:464-71. doi: 10.3899/jrheum.140370

84. Mandl T, Diaz S, Ekberg O, Hesselstrand R, Piitulainen E, Wollmer P, et al. Frequent development of chronic obstructive pulmonary disease in primary SS-results of a longitudinal follow-up. Rheumatology. (2012) 51:941-6. doi: 10.1093/rheumatology/ker409

85. Roca F, Dominique S, Schmidt J, Smail A, Duhaut P, Levesque H, et al. Interstitial lung disease in primary Sjögren's syndrome. Autoimmun Rev. (2017) 16:48-54. doi: 10.1016/j.autrev.2016.09.017

86. Lechtman S, Debray MP, Crestani B, Bancal C, Hourseau M, Dossier A, et al. Cystic lung disease in Sjögren's syndrome: an observational study. Joint Bone Spine. (2017) 84:317-21. doi: 10.1016/j.jbspin.2016.05.019

87. Swigris JJ, Berry GJ, Raffin TA, Kuschner WG. Lymphoid interstitial pneumonia: a narrative review. Chest. (2002) 122:2150-64. doi: $10.1378 /$ chest.122.6.2150

88. Tanner K, Nissen SL, Merrill RM, Miner A, Channell RW, Miller KL, et al. Nebulized isotonic saline improves voice production in Sjögren's syndrome. Laryngoscope. (2015) 125:2333-40. doi: 10.1002/lary.25239

89. Stalenheim G, Gudbjornsson B. Anti-inflammatory drugs do not alleviate bronchial hyperreactivity in Sjögren's syndrome. Allergy. (1997) 52:423-7. doi: 10.1111/j.1398-9995.1997.tb01022.x

90. Deheinzelin D, Capelozzi VL, Kairalla RA, Barbas Filho JV, Saldiva $\mathrm{PH}$, de Carvalho CR. Interstitial lung disease in primary Sjögren's syndrome. clinical-pathological evaluation and response to treatment. Am J Respir Crit Care Med. (1996) 154:794-9. doi: 10.1164/ajrccm.154.3.88 10621

91. Oldham JM, Lee C, Valenzi E, Witt LJ, Adegunsoye A, Hsu S, et al. Azathioprine response in patients with fibrotic connective tissue disease-associated interstitial lung disease. Respir Med. (2016) 121:117-22. doi: 10.1016/j.rmed.2016.11.007

92. Barnes H, Holland AE, Westall GP, Goh NS, Glaspole IN. Cyclophosphamide for connective tissue disease-associated interstitial lung disease. Cochrane Database Syst Rev. (2018) 1:CD010908. doi: 10.1002/14651858.CD010908.pub2

93. Zhang L, Mo H, Zhu M, Wang L. Effect of cyclophosphamide on cytokines in patients with primary Sjögren's syndrome-associated interstitial lung disease in South China. Rheumatol Int. (2013) 33:1403-7. doi: 10.1007/s00296-012-2561-7

94. Fischer A, Brown KK, Du Bois RM, Frankel SK, Cosgrove GP, FernandezPerez ER, et al. Mycophenolate mofetil improves lung function in connective tissue disease-associated interstitial lung disease. J Rheumatol. (2013) 40:6406. doi: 10.3899/jrheum.121043

95. Chen MH, Chen CK, Chou HP, Chen MH, Tsai CY, Chang DM. Rituximab therapy in primary Sjögren's syndrome with interstitial lung disease: a retrospective cohort study. Clin Exp Rheumatol. (2016) 34:1077-84.

96. Adler S, Korner M, Forger F, Huscher D, Caversaccio MD, Villiger PM. Evaluation of histologic, serologic, and clinical changes in response to abatacept treatment of primary Sjögren's syndrome: a pilot study. Arthritis Care Res. (2013) 65:1862-8. doi: 10.1002/acr.22052

97. Langley RG, Elewski BE, Lebwohl M, Reich K, Griffiths CE, Papp K, et al. Secukinumab in plaque psoriasis-results of two phase 3 trials. $N$ Engl J Med. (2014) 371:326-38. doi: 10.1056/NEJMoa1314258

98. Mease PJ, McInnes IB, Kirkham B, Kavanaugh A, Rahman P, van der Heijde $D$, et al. Secukinumab Inhibition of Interleukin-17A in patients with psoriatic arthritis. N Engl J Med. (2015) 373:1329-39. doi: 10.1056/NEJMoa1412679

99. Gordon KB, Blauvelt A, Papp KA, Langley RG, Luger T, Ohtsuki M, et al. Phase 3 trials of ixekizumab in moderate-to-severe plaque psoriasis. N Engl J Med. (2016) 375:345-56. doi: 10.1056/NEJMoa1512711

100. Furie R, Khamashta M, Merrill JT, Werth VP, Kalunian K, Brohawn P, et al. Anifrolumab, an anti-interferon-alpha receptor monoclonal antibody, in moderate-to-severe systemic lupus erythematosus. Arthritis Rheumatol. (2017) 69:376-86. doi: 10.1002/art.39962

101. Lee J, Lee J, Kwok SK, Baek S, Jang SG, Hong SM, et al. Janus kinase 1 inhibition suppresses interferon-induced B cell activating factor production in human salivary gland: potential therapeutic strategy for primary Sjögren's syndrome. Arthritis Rheumatol. (2018) 70:2057-66. doi: 10.1002/art.40589

102. Gadina M, Johnson C, Schwartz D, Bonelli M, Hasni S, Kanno Y, et al. Translational and clinical advances in JAK-STAT biology: the present and future of jakinibs. J Leukoc Biol. (2018) 104:499-514. doi: 10.1002/JLB.5RI0218-084R

103. Barnes PJ. Kinases as novel therapeutic targets in asthma and chronic obstructive pulmonary disease. Pharmacol Rev. (2016) 68:788-815. doi: $10.1124 /$ pr.116.012518

104. Milara J, Hernandez G, Ballester B, Morell A, Roger I, Montero P, et al. The JAK2 pathway is activated in idiopathic pulmonary fibrosis. Respir Res. (2018) 19:24. doi: 10.1186/s12931-018-0728-9

Conflict of Interest Statement: The authors declare that the research was conducted in the absence of any commercial or financial relationships that could be construed as a potential conflict of interest.

Copyright (c) 2019 Gupta, Ferrada and Hasni. This is an open-access article distributed under the terms of the Creative Commons Attribution License (CC BY). The use, distribution or reproduction in other forums is permitted, provided the original author(s) and the copyright owner(s) are credited and that the original publication in this journal is cited, in accordance with accepted academic practice. No use, distribution or reproduction is permitted which does not comply with these terms. 